\title{
Phytoremediation of Trace Metal Polluted Soil with Fiber Crop: Kenaf (Hibiscus Cannabinus L.)
}

\author{
Sarra Arbaoui ${ }^{1}$, Sihem SOUFI ${ }^{1}$, Paul Roger ${ }^{2}$ et Taoufik Bettaieb ${ }^{1}$
}

\begin{abstract}
Cleaning up polluted soil by trace metals was investigated through evaluating the potential of kenaf (Hibiscus cannabinus L.) to extract and accumulate cadmium (Cd) and zinc $(\mathrm{Zn})$ in its tissues. Soil pollution is due to its irrigation by treated wastewater for more than two decades. Kenaf was cultivated in two plots in a suburban site; one was irrigated by treated wastewater (S2) and the second was irrigated by non-polluted water (S1). Results showed that kenaf plants grow up in both plots with no significant differences. After the culture, $\mathrm{Zn}$ and $\mathrm{Cd}$ soil contents decrease respectively of $140.85 \mathrm{mg}$ and about $4.5 \mathrm{mg} \mathrm{Cd} / \mathrm{kg}$. This study showed that kenaf is able to accumulate in its tissues about $140 \mathrm{mg}$ of $\mathrm{Zn}$ and about $4.5 \mathrm{mg} \mathrm{Cd} / \mathrm{kg}$ dry matter in one single crop.
\end{abstract}

Keywords — kenaf, phytoremediation, zinc, cadmium.

\section{INTRODUCTION}

In the Mediterranean region, water is a scarce and sources are naturally limited. In Tunisia, and near major urban sites, many peri-urban agricultural areas are irrigated by treated wastewater from different treatment stations. However, if this resource represents a water value and potential contribution of minerals, it is also a source of pollution. Its content in metallic trace elements (ETM) such as copper, zinc, cadmium, lead ... and metalloids such as boron, silicon ... are involved in chemical pollution of soils. Soil pollution by ETM also results from the alteration of the basic materials and human activity, as the inputs of sludge, mining, urban and industrial waste... [1]. some of these metals, such as zinc, are essential for the growth and development of plants. However, their presence in the soil with high doses is toxic. Other non-essential metals such as cadmium, are phototoxic, even at low concentrations [2;3].

Soil decontamination can be achieved by physicochemical and biological treatments. The physico-chemical methods are costly and require specific equipment in addition to their negative effects on the ecosystem. Among the biological methods, phytoremediation, which is less costly respectful of the environment and based on the use of plants accumulating salts and metal, is increasingly used for soil remediation, wastewater or water air $[4 ; 5]$. This technique is based on the phytoextraction of pollutants from soil through

\footnotetext{
${ }^{1}$ Horticultural Science Laboratory, National Institute of Agricultural Science, University of Carthage, Tunisia

${ }^{2}$ Environmental Toxicology laboratory, Gembloux Agro Bio Tech, University of Liege, Belgium
}

plants able that areto concentrate in their tissue. The mechanisms developed by plants to resist or to accumulate large quantities of metals have been well studied, especially to identify hyperaccumulating plant species, namely, plants that accumulate trace metals to more than $1 \%$ in their aerial parts without presenting any phytotoxic effects [6]. However, most of these species develop low biomass and accumulate, low amounts of metals extracted from the ground. Therefore, for better efficacy of this technique, it is wise to identify plants with high biomass and hyperaccumulating ability of ETM. Indeed, among the plants that can meet these criteria, kenaf (Hibiscus cannabinus L.) is an annual belonging to the Malvaceae family was chosen because it is on the one hand, characterized by rapid growth and high biomass and secondly, its use as a source of fiber multipurpose as manufacturing biomaterials, pulp and textile ... and does not constitute a risk to human health and the environment.

In order to determine the phytoremediation potential of kenaf, trials was conducted on soil polluted by ETM due to its irrigation with treated wastewater for several years. The accumulating ability of cadmium and zinc was also investigated.

\section{MATERIALS AND METHOD}

\section{A. Soil and Plants}

Plants of kenaf (Hibiscus cannabinus L.), cultivar Tainung 2 were grown in a suburban site, on two plots, one irrigated by treated wastewater for two decades (S2) and the other nonirrigated by this polluted water (S1). The chemical characteristics of irrigation water are shown in Table 1.

The trial has lasted from May to October. During this period characterized by scarce rainfall and high temperatures (Table 2 ), the plants were irrigated with polluted wastewater (PWW) or clean drinking water $(\mathrm{CW})$. The test was carried out using a completely random block design with 3 repetitions included the following treatments.

- T1 (control): S1 irrigated with clean water (CW)

- T2: S1 irrigated with polluted wastewater (PWW)

- T3: S2 irrigated with clean water (CW)

- T4: S2 irrigated with polluted wastewater (PWW)

Soil physicochemical characteristics of the two plots have no significant differences (Table 3). It is a light soil composed of clay (9.5\%), silt (23\%), and sand (66\%). 
TABLE I: CHEMICAL CHARACTERISTICS OF IRRIGATION WATER*

\begin{tabular}{lcccc}
\hline & $\mathrm{pH}$ & Salinity $\left(\mathrm{g} . \mathrm{I}^{-1}\right)$ & $\mathrm{Cd}\left(\mu \mathrm{g} . \mathrm{I}^{-1}\right)$ & $\begin{array}{c}\mathrm{Zn}\left(\mu \mathrm{g} . \mathrm{l}^{-}\right. \\
1)\end{array}$ \\
\hline $\begin{array}{l}\text { Water } \\
\text { unpolluted }\end{array}$ & 7,4 & 1.04 & 00 & 00 \\
Waste water & 7.8 & 2.3 & 30 & 180 \\
\hline \hline
\end{tabular}

*Averages of three samples

TABLE II: ENVIRONMENTAL CONDITIONS DURING THE GROWING SEASON

\begin{tabular}{lccc}
\hline \hline Months & $\begin{array}{c}\text { Average } \\
\text { maximum } \\
\text { temperatures }\left({ }^{\circ} \mathrm{C}\right)\end{array}$ & $\begin{array}{c}\text { Average minimum } \\
\text { temperatures }\left({ }^{\circ} \mathrm{C}\right)\end{array}$ & $\begin{array}{c}\text { Pluviometer } \\
(\mathrm{mm})\end{array}$ \\
\hline May & 24,2 & 15 & 14 \\
June & 28,1 & 18,1 & 7 \\
July & 31 & 21 & 1 \\
August & 32,1 & 22,4 & 8 \\
September & 29,1 & 20,7 & 32 \\
October & 25,3 & 16,6 & 61 \\
\hline Averages & 28,1 & 18,9 & 123 \\
\hline \hline
\end{tabular}

TABLE III: PHYSICAL AND CHEMICAL CHARACTERISTCS OF THE SOIL OF THE TWO PARCELS S1 AND S2

\begin{tabular}{|c|c|c|c|c|c|c|c|}
\hline \multicolumn{2}{|c|}{$\overline{\mathrm{pH}}$} & \multicolumn{2}{|c|}{$\mathrm{C}_{\mathrm{ang}}(\mathrm{g} / \mathrm{kg} \mathrm{MS})^{*}$} & \multicolumn{2}{|c|}{$\mathrm{C} / \mathrm{N}$} & \multicolumn{2}{|c|}{$\% \mathrm{MO}^{88}$} \\
\hline $\begin{array}{l}\text { S1 } \\
6,3\end{array}$ & $\begin{array}{l}52 \\
6,6\end{array}$ & $\begin{array}{c}S 1 \\
62,83\end{array}$ & $\begin{array}{c}\$ 2 \\
60,74\end{array}$ & $\begin{array}{l}\text { S1 } \\
6,3\end{array}$ & $\begin{array}{l}52 \\
6,6\end{array}$ & $\begin{array}{c}\$ 1 \\
62.83\end{array}$ & $\begin{array}{c}\$ 2 \\
60,74\end{array}$ \\
\hline
\end{tabular}

$* * \mathrm{C}_{\mathrm{org}}$ : Organic carbon

** MO :Organic matter

\section{B. Measured Parameters and Analysis}

Monitoring and analysis had concerned growth parameters and analysis of $\mathrm{Zn}$ and $\mathrm{Cd}$ contents in soil samples and plants. Growth parameters were performed at the end of culture through measurements of plant height, stem diameter at height of $2 \mathrm{~cm}$ from the collar and dry matter of the vegetative part and the root part.

$\mathrm{Zn}$ and $\mathrm{Cd}$ contents in soil and plants were determined after three months culture. The different parts of the plant are harvested (root, stalk and leaf) and dried in an oven at $80^{\circ} \mathrm{C}$ for 48 hours.

Samples of $0.5 \mathrm{~g}$ of dry matter from each treatment were placed in a silica crucible and placed in a muffle furnace at $450{ }^{\circ} \mathrm{C}$ for 4 hours. The ash was then dissolved in $5 \mathrm{ml}$ of $20 \% \mathrm{HCl}$. Soil samples are dried, crushed and mineralized by $\mathrm{HNO} 3$ and $\mathrm{HCl} 4$. The concentrations of $\mathrm{Cd}$ and $\mathrm{Zn}$ in soil and different plant parts are then determined by spectrophotometry anatomical absorption.

The results were analyzed by ANOVA statistical test and the test LSD at 5\%.

\section{RESULTS AND DISCUSSION}

\section{A. Effects of Treated Wastewater on Kenaf Plant Growth}

Observations realized on kenaf plants grown on a contaminated soil, due to its irrigation with wastewater for many years, have shown that kenaf growth did not vary significantly comparing to plant control cultivated on unpolluted soil (Fig. 1, 2 and 3). Indeed, kenaf vegetate in all treatments without any apparent differences and no phytotoxicity on both plots. No significant difference was observed on plant height (Fig. 1), stem diameter (Fig. 2) and dry matter of (Figure 3). This is shows the tolerance of kenaf to ETM present in the soil. These results confirmed those of Cartago et al. [9] who reported that this plant can be grown on soils contaminated with mercury, cadmium, copper and chromium without reducing productivity and those of Arbaoui and Ben Salah [10] which confirm these findings indicating an equivalent performance of kenaf irrigated with treated wastewater.

\section{B. Zn and Cd contents in plants}

At the end of the culture indicated by the yellowing of the foliage, chemical analysis of the dry matter showed that the accumulation of $\mathrm{Zn}$ and $\mathrm{Cd}$ by Hibiscus cannabinus $\mathrm{L}$. in different parts differs significantly depending on the plots of culture and the irrigation water quality (Fig. 4 and 5). In effect, the highest metal contents in plants, approximately $140.85 \mathrm{mg}$ of $\mathrm{Zn}$ and approximately $4.78 \mathrm{mg}$ of $\mathrm{Cd} / \mathrm{kg}$ dry matter, were obtained from those grown on irrigated soils for two decades and during a growing season in treated wastewater. These quantities do not exceed $107.44 \mathrm{mg}$ of $\mathrm{Zn}$ and $0.23 \mathrm{mg} \mathrm{Cd} / \mathrm{kg}$ dry matter on the soil that has not never been irrigated by wastewater before. In treatments 2 and $3, \mathrm{Zn}$ and $\mathrm{Cd}$ contents in plants had intermediate values.

The high amounts of $\mathrm{Zn}$ and $\mathrm{Cd}$ in Hibiscus cannabinus $\mathrm{L}$. plants have accumulated indicates firstly, a metal contamination of soils irrigated with wastewater and the ability of this plant to extract and accumulate these metals. Indeed, the water used for irrigation is rich in ETM and essentially the $\mathrm{Cd}$ with a concentration of $30 \mu \mathrm{g} / 1$ far exceeding the recommended maximum for irrigation waters that is $10 \mathrm{mg} / 1$ [13]. The effectiveness of phytorextraction depends mainly on the choice of plant species must be not only tolerant but also able to accumulate trace metals in their tissues. Absorption and translocation of trace metals in plants vary widely between plant species, but also among the cultivars of the same species. The cultivar Tainning 2 of kenaf utilised in this study seems effective in extracting $\mathrm{Zn}$ and $\mathrm{Cu}$ from the soil. From the results of Figure 4 and 5, it has been also shown that $\mathrm{Zn}$ levels are still higher than those of $\mathrm{Cd}$ and the highest concentrations of the two elements, in all situations and with all treatments, are present in roots of Hibiscus cannabinus L. These quantities can reach in the roots of plants grown on polluted and irrigated soil by wastewater $65.33 \mathrm{mg}$ of $\mathrm{Zn}$ and $2.67 \mathrm{mg} \mathrm{Cd} / \mathrm{kg}$ dry matter. This ability to accumulate $\mathrm{Cd}$ confirms the observations of Nabulo et al. [8] showing that kenaf can raise $3.3 \mathrm{mg} \mathrm{Cd} / \mathrm{kg}$ of dry matter. It is also important to note that although the concentrations of $\mathrm{Zn}$ and $\mathrm{Cd}$ are less important in the dry matter of the shoots and then leaves, accumulated amounts by the above ground part, in this case, are much larger than those of the roots due to the high biomass produced in this part of the plant (Fig. 4 and 5).

\section{Zn and Cd Soil content before and after harvest}

Soil Analysis realised before and after culture showed varying amounts of ETM regardless the treatment (Fig. 6 and 7). Indeed, a decrease of metal content in soil after plant harvest was noted; about 3- $4 \mathrm{mg}$ of $\mathrm{Zn}$ and and about $0.2 \mathrm{mg}$ of $\mathrm{Cd}$ per $\mathrm{kg}$ of soil. Therefore, it appears that kenaf has a 
major extraction capacity of ETM from soil and can accumulate them in its tissues despite their phytotoxicity. It is recognized that the effectiveness of phytoextraction of metals is related to the ability of the species to grow on polluted soil and produce a large biomass in the above ground parts. According to trace metal extracted amount, it can be concluded that decontamination by kenaf is possible. However, this process could be quite long in time. Others industrial plants with important biomass are recently recommended for phytoremediation such as Roselle (Hibiscus sabdariffa L.), an annual species that belongs to the same genus as kenaf [12] and Averrhoa caramboles L. cultivated for the wood production that is able to extract $50 \%$ of total $\mathrm{Cd}$ from contaminated soil after 13 years of culture on the same site [13].

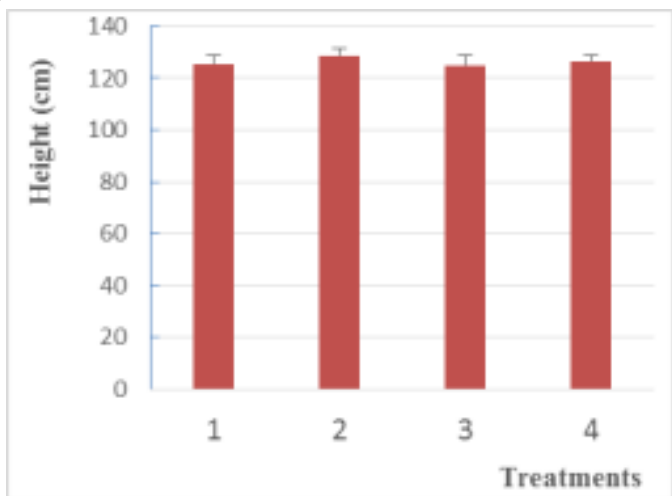

Fig.1: Effects of treated wastewater on height growth

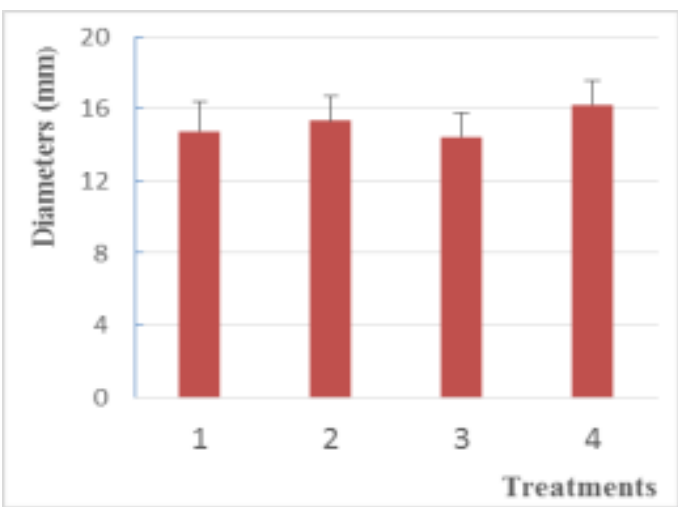

Fig.2: Effects of treated wastewater on growth stem diameter

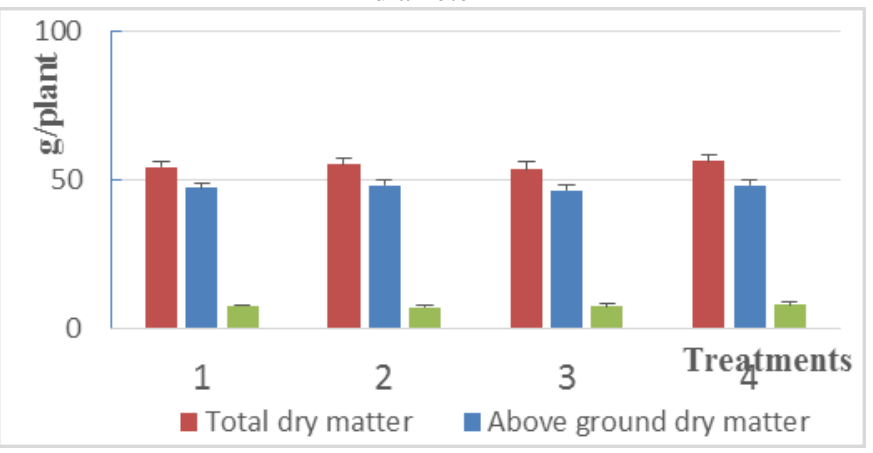

Fig. 3: Effects of treated wastewater on dry matter production

T1 (Control): S1 irrigated with clean water (CW)

T2: S1 irrigated with polluted wastewater (PWW)

T3: S2 irrigated with clean water (CW)

T4: S2 irrigated with polluted wastewater (PWW)

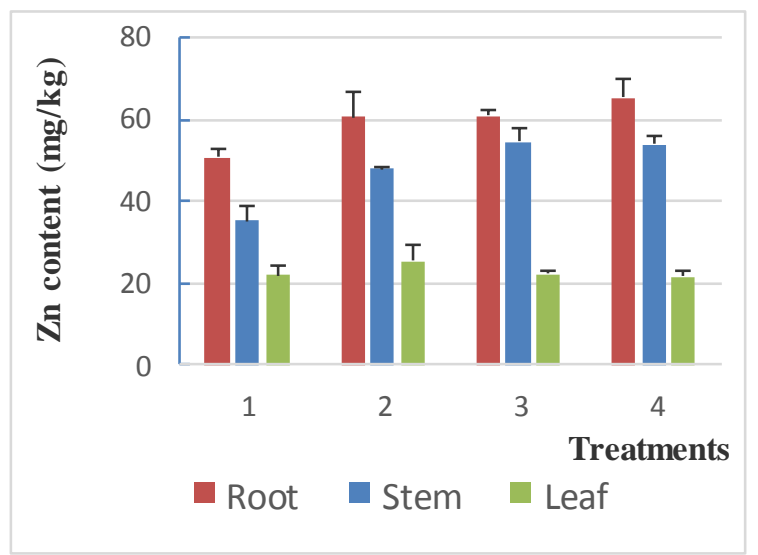

Fig. 4: Zn content in plants at the end of culture



Fig. 5: Cd content in plants at the end of culture



Fig. 6: $\mathrm{Zn}$ content in soil before and after harvest 




Fig. 7: Cd content in soil before and after harvest

T1 (Control): S1 irrigated with clean water (CW)

T2: S1 irrigated with polluted wastewater (PWW)

T3: S2 irrigated with clean water $(\mathrm{CW})$

T4: S2 irrigated with polluted wastewater (PWW)

\section{CONCLUSION}

Kenaf (Hibiscus cannabinus L.) grown on a suburban plot contaminated by $\mathrm{Zn}$ and $\mathrm{Cd}$ due to its irrigation by wastewater for two decades

- vegetate without any signs of phytotoxicity,

- produced large biomass,

- accumulating in its tissues about $140 \mathrm{mg}$ of $\mathrm{Zn}$ and about $4.5 \mathrm{mg}$ of $\mathrm{Cd} / \mathrm{kg}$ dry matter,

- allows a reduction of soil ETM contents about $140.85 \mathrm{mg}$ $\mathrm{Zn}$ and about $4.5 \mathrm{mg} \mathrm{Cd} / \mathrm{kg}$ in one culture.

These results allow suggesting that kenaf (Hibiscus cannabinus L.) can be used as a biological method for the remediation of contaminated soil by ETM for its high capacity to extraction $\mathrm{Zn}$ and $\mathrm{Cd}$ from the soil and raise them in its tissues despite their phytotoxicity. However, this decontamination process seems to be long.

\section{ACKNOWLEDGMENTS}

A special thanks to " Ford Motor Company Conservation and Environmental Program " for the financial support of this research.

\section{REFERENCES}

[1] A. Kabata-Pendias, H. Pendias. Trace Elements in Soils and Plants, CRC Press LLC, Boca Raton, Florida, 2001, 432 pp.

[2] M.M. Lasat. Phytoextraction of toxic metals: a review of biological mechanisms. Journal of Environmental Quality, 31,2002, pp. 109-20. http://dx.doi.org/10.2134/jeq2002.0109

[3] M. Bertrand, I. Poirier. Photosynthetic organisms and excess of metals. Photosynthetica 43,2005,pp. 345-353. http://dx.doi.org/10.1007/s11099-005-0058-2

[4] I. Raskin, N.P.B.A. Kumar, S. Dushenkov, D.E. Salt. Bioconcentration of heavy metal by plants. CurrOpinBiotechnol 5,1994, pp. 285-290. http://dx.doi.org/10.1016/0958-1669(94)90030-2

[5] D.E. Salt, M. Blaylock, N.P.B.A. Kumar, V. Dushenkov, B.D. Ensley, I. Chet, I. Raskin. Phytoremediation : a novel strategy for the removal of toxic metals from the environment using plants. Biotechnology, 13,1995, pp. 468-474. http://dx.doi.org/10.1038/nbt0595-468

[6] N. Rascio, F. Navari-Izzo. Heavy metal hyperaccumulating plants: how and why do they do it? And what makes them so interesting. Plant Science, 2,2011, pp. 169-181. http://dx.doi.org/10.1016/j.plantsci.2010.08.016

[7] C. Schwartz, S. Guimont, C. Saison, K. Perronnet, J.L. Morel. Phytoextraction of $\mathrm{Cd}$ and $\mathrm{Zn}$ by the hyperaccumulator plant Thlaspicaerulescens as affected by plant size and origin, South Afr. J. Sci, 97,2001, pp. 561-564.

[8] G. Nabulo, C.R. Black, S.D. Young. Trace metal uptake by tropical vegetables grown on soil amended with urban sewage sludge. Environ Pollut, 15,2011, pp. 368-376. http://dx.doi.org/10.1016/j.envpol.2010.11.007

[9] A. Cartoga, A. Fernando, J.S. Oliveira. Effects on growth, productivity and biomass quality of kenaf of soils contaminated with heavy metals. SciRef Cosmos, 4, 2005, pp1-4.

[10] S. Arbaoui et H. Ben Salah.Effets de la qualité de l'eau d'irrigation sur le rendement et la qualité d'une plante industrielle: le kenaf (Hibiscus cannabinus L.). Revue de l'INAT, 26, 2012, pp. 34-39.

[11] M. A. Smith. Retention of bacteria, viruse and heavy metal on cops irrigated reclaimed water. Australian Water Resources Council, 74,1982, pp. 206- 246.

[12] N. Anyinkeng, A.M. Mih. Soil nutrient supplementation on growth and biomass production of roselle under tropical conditions. AgricBiol J N Am., 2, 2011, pp. 603-609.

[13] J.T. Li, B. Liao, Z.Y. Dai, R. Zhu and W.S. Shu. Phytoextraction of Cdcontaminated soil by carambola (Averrhoa carambola) in field trials. Chemosphere, 76, 2009, pp.1233-1239.

http://dx.doi.org/10.1016/j.chemosphere.2009.05.042 